4

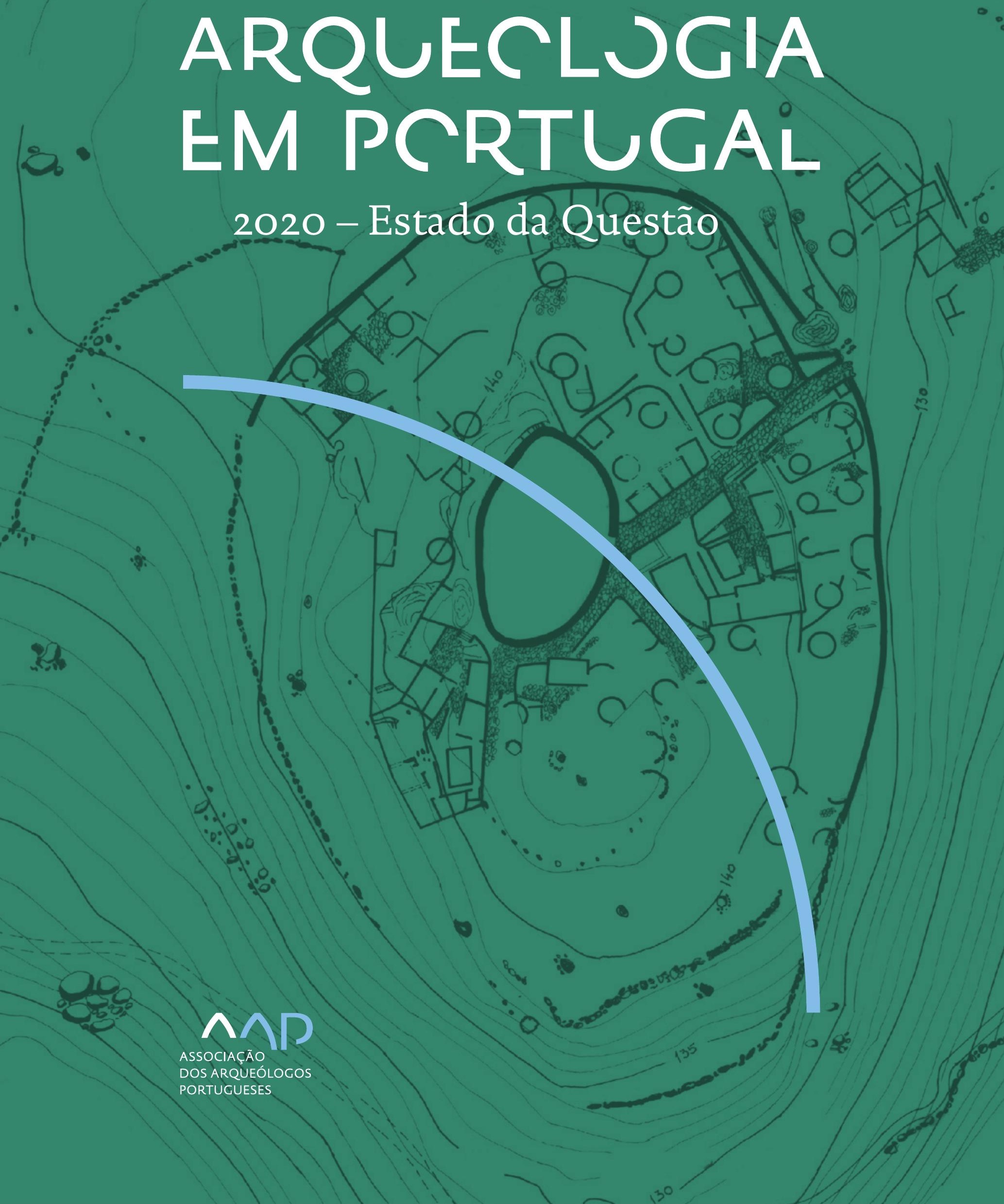


Coordenação editorial: José Morais Arnaud, César Neves e Andrea Martins Design gráfico: Flatland Design

AAP - ISBN: 978-972-9451-89-8

CITCEM - ISBN: 978-989-8970-25-1

Associação dos Arqueólogos Portugueses e CITCEM

Lisboa, 2020

O conteúdo dos artigos é da inteira responsabilidade dos autores. Sendo assim a Associação dos Arqueólogos Portugueses declina qualquer responsabilidade por eventuais equívocos ou questões de ordem ética e legal.

Desenho de capa:

Planta do castro de Monte Mozinho (Museu Municipal de Penafiel).

\section{$\hat{\wedge} \mathrm{P}$}

DOS ARQUEÓLOGOS PORTUGUESES

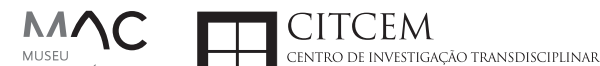
MUSEU
ARQUELLÓGICO
DO CARMO
U.PORTO

FLUP FACULDADE DE LETRAS
UNIVERSIDADE DO PORTO

Apoio

EC para a Ciência 


\section{Índice}

15 Prefácio

José Morais Arnaud

\section{Historiografia e Teoria}

17 Território, comunidade, memória e emoção: a contribuição da história da arqueologia (algumas primeiras e breves reflexões)

Ana Cristina Martins

25 Como descolonizar a arqueologia portuguesa?

Rui Gomes Coelho

41 Arqueologia e Modernidade: uma revisitação pessoal e breve de alguns aspetos da obra homónima de Julian Thomas de 2004

Vítor Oliveira Jorge

57 Dados para a História das Mulheres na Arqueologia portuguesa, dos finais do século XIX aos inícios do século XX: números, nomes e tabelas

Filipa Dimas / Mariana Diniz

73 Retractos da arqueologia portuguesa na imprensa: (in)visibilidades no feminino

Catarina Costeira / Elsa Luís

85 Arqueologia e Arqueólogos no Norte de Portugal Jacinta Bugalhão

101 Vieira Guimarães (1864-1939) e a arqueologia em Tomar: uma abordagem sobre o território e as gentes

João Amendoeira Peixoto / Ana Cristina Martins

115 Os memoráveis? A arqueologia algarvia na imprensa nacional e regional na presente centúria (2001-2019): características, visões do(s) passado(s) e a arqueologia

enquanto marca

Frederico Agosto / João Silva

129 A Evolução da Arqueologia Urbana e a Valorização Patrimonial no Barlavento Algarvio: Os casos de Portimão e Silves

Artur Mateus / Diogo Varandas / Rafael Boavida

\section{Gestão, Valorização e Salvaguarda do Património}

145 O Caderno Reivindicativo e as condições de trabalho em Arqueologia Miguel Rocha / Liliana Matias Carvalho / Regis Barbosa / Mauro Correia / Sara Simões / Jacinta Bugalhão / Sara Brito / Liliana Veríssimo Carvalho / Richard Peace / Pedro Peça / Cézer Santos

155 Os Estudos de Impacte Patrimonial como elemento para uma estratégia sustentável de minimização de impactes no âmbito de reconversões agrícolas Tiago do Pereiro

165 Salvaguarda de Património arqueológico em operações florestais: gestão e sensibilização Filipa Bragança / Gertrudes Zambujo / Sandra Lourenço / Belém Paiva / Carlos Banha / Frederico Tatá Regala / Helena Moura / Jacinta Bugalhão / João Marques / José Correia / Pedro Faria / Samuel Melro

179 Os valores do Património: uma investigação sobre os Sítios Pré-históricos de Arte Rupestre do Vale do Rio Côa e de Siega Verde José Paulo Francisco 
189 Conjugando recursos arqueológicos e naturais para potenciar as visitas ao Geoparque Litoral de Viana do Castelo (Noroeste de Portugal)

Hugo A. Sampaio / Ana M.S. Bettencourt / Susana Marinho / Ricardo Carvalhido

203 Áreas de Potencial Arqueológico na Região do Médio Tejo: Modelo Espacial Preditivo Rita Ferreira Anastácio / Ana Filipa Martins / Luiz Oosterbeek

223 Património Arqueológico e Gestão Territorial: O contributo da Arqueologia para a revisão do PDM de Avis

Ana Cristina Ribeiro

237 A coleção arqueológica do extinto Museu Municipal do Porto - Origens, Percursos e Estudos

Sónia Couto

251 Valpaços - uma nova carta arqueológica

Pedro Pereira / Maria de Fátima Casares Machado

263 Arqueologia na Cidade de Peniche

Adriano Constantino / Luís Rendeiro

273 Arqueologia Urbana: a cidade de Lagos como caso de Estudo Cátia Neto

285 Estratégias de promoção do património cultural subaquático nos Açores. O caso da ilha do Faial

José Luís Neto / José Bettencourt / Luís Borges / Pedro Parreira

297 Carta Arqueológica da Cidade Velha: Uma primeira abordagem

Jaylson Monteiro / Nireide Tavares / Sara da Veiga / Claudino Ramos / Edson Brito /

Carlos Carvalho / Francisco Moreira / Adalberto Tavares

311 Antropologia Virtual: novas metodologias para a análise morfológica e funcional Ricardo Miguel Godinho / Célia Gonçalves

\section{Didáctica da Arqueologia}

327 Como os projetos de Arqueologia podem contribuir para uma comunidade culturalmente mais consciente Alexandra Figueiredo / Claúdio Monteiro / Adolfo Silveira / Ricardo Lopes

337 Educação Patrimonial - Um cidadão esclarecido é um cidadão ativo! Ana Paula Almeida

351 A aproximação da Arqueologia à sala de aula: um caso de estudo no $3^{\circ}$ ciclo do Ensino Básico Luís Serrão Gil

363 Arqueologia 3.o - Pensar e comunicar a Arqueologia para um futuro sustentável Mónica Rolo

377 “Conversa de Arqueólogos" - Divulgar a Arqueologia em tempos de Pandemia Diogo Teixeira Dias

389 Escola Profissional de Arqueologia: desafios e oportunidades Susana Nunes / Dulcineia Pinto / Júlia Silva / Ana Mascarenhas

399 Os Museus de Arqueologia e os Jovens: a oferta educativa para o público adolescente Beatriz Correia Barata / Leonor Medeiros

411 O museu universitário como mediador entre a ciência e a sociedade: o exemplo da secção de arqueologia no Museu de História Natural e da Ciência da Universidade do Porto (MHNC-UP)

Rita Gaspar 
421 Museu de Lanifícios: Real Fábrica de Panos. Atividades no âmbito da Arqueologia Beatriz Correia Barata / Rita Salvado

427 Arqueologia Pública e o caso da localidade da Mata (Torres Novas) Cláudia Manso / Ana Rita Ferreira / Cristiana Ferreira / Vanessa Cardoso Antunes

431 Do sítio arqueológico ao museu: um percurso (também) didático Lídia Fernandes

447 Estão todos convidados para a Festa! E para dançar também... O projecto do Serviço Educativo do Museu Arqueológico do Carmo na $5^{\underline{a}}$ Edição da Festa da Arqueologia Rita Pires dos Santos

459 O “Clã de Carenque”, um projeto didático de arqueologia Eduardo Gonzalez Rocha

469 Mediação cultural: peixe que puxa carroça nas Ruínas Romanas de Troia Inês Vaz Pinto / Ana Patrícia Magalhães / Patrícia Brum / Filipa Santos

481 Didática Arqueológica, experiências do Projeto Mértola Vila Museu Maria de Fátima Palma / Clara Rodrigues / Susana Gómez / Lígia Rafael

\section{Arte Rupestre}

497 Os inventários de arte rupestre em Portugal Mila Simões de Abreu

513 O projeto FIRST-ART - conservação, documentação e gestão das primeiras manifestações de arte rupestre no Sudoeste da Península Ibérica: as grutas do Escoural e Maltravieso Sara Garcês / Hipólito Collado / José Julio García Arranz / Luiz Oosterbeek / António Carlos Silva / Pierluigi Rosina / Hugo Gomes / Anabela Borralheiro Pereira / George Nash / Esmeralda Gomes / Nelson Almeida / Carlos Carpetudo

523 Trabalhos de documentação de arte paleolítica realizados no âmbito do projeto PalæoCôa André Tomás Santos / António Fernando Barbosa / Luís Luís / Marcelo Silvestre / Thierry Aubry

537 Imagens fantasmagóricas, silhuetas elusivas: as figuras humanas na arte do Paleolítico Superior da região do Côa Mário Reis

$55^{1}$ Os motivos zoomórficos representados nas placas de tear de Vila Nova de São Pedro (Azambuja, Portugal) Andrea Martins / César Neves / José M. Arnaud / Mariana Diniz

571 Arte Rupestre do Monte de Góios (Lanhelas, Caminha). Síntese dos resultados dos trabalhos efectuados em 2007-2009 Mário Varela Gomes

599 Gravuras rupestres de barquiformes no Monte de S. Romão, Guimarães, Noroeste de Portugal Daniela Cardoso

613 Círculos segmentados gravados na Bacia do Rio Lima (Noroeste de Portugal): contributos para o seu estudo Diogo Marinho / Ana M.S. Bettencourt / Hugo Aluai Sampaio

631 Equídeos gravados no curso inferior do Rio Mouro, Monção (NW Portugal). Análise preliminar Coutinho, L.M. / Bettencourt, A.M.S / Sampaio, Hugo A.S

645 Paletas na Arte Rupestre do Noroeste de Portugal. Inventário preliminar Bruna Sousa Afonso / Ana M. S. Bettencourt / Hugo A. Sampaio 


\section{Pré-História}

661 O projeto Miño/Minho: balanço de quatro anos de trabalhos arqueológicos Sérgio Monteiro-Rodrigues / João Pedro Cunha-Ribeiro / Eduardo Méndez-Quintas / Carlos Ferreira / Pedro Xavier / José Meireles / Alberto Gomes / Manuel Santonja / Alfredo Pérez-González

677 A ocupação paleolítica da margem esquerda do Baixo Minho: a indústria lítica do sítio de Pedreiras 2 (Monção, Portugal) e a sua integração no contexto regional Carlos Ferreira / João Pedro Cunha-Ribeiro / Sérgio Monteiro-Rodrigues / Eduardo Méndez-Quintas / Pedro Xavier / José Meireles / Alberto Gomes / Manuel Santonja / Alfredo Pérez-González

693 O sítio acheulense do Plistocénico médio da Gruta da Aroeira Joan Daura / Montserrat Sanz / Filipa Rodrigues / Pedro Souto / João Zilhão

703 As sociedades neandertais no Barlavento algarvio: modelos preditivos com recurso aos SIG

Daniela Maio

715 A utilização de quartzo durante o Paleolítico Superior no território dos vales dos rios Vouga e Côa

Cristina Gameiro / Thierry Aubry / Bárbara Costa / Sérgio Gomes / Luís Luís / Carmen Manzano / André Tomás Santos

733 Uma perspetiva diacrónica da ocupação do concheiro do Cabeço da Amoreira (Muge, Portugal) a partir da tecnologia lítica Joana Belmiro / João Cascalheira / Célia Gonçalves

745 Novos dados sobre a Pré-história Antiga no concelho de Palmela. A intervenção arqueológica no sítio do Poceirão I

Michelle Teixeira Santos

757 Problemas em torno de Datas Absolutas Pré-Históricas no Norte do Alentejo Jorge de Oliveira

771 Povoamento pré-histórico nas áreas montanhosas do NO de Portugal: o Abrigo 1 de Vale de Cerdeira Pedro Xavier / José Meireles / Carlos Alves

783 Apreciação do povoamento do Neolítico Inicial na Baixa Bacia do Douro. A Lavra I (Serra da Aboboreira) como caso de estudo Maria de Jesus Sanches

797 O Processo de Neolitização na Plataforma do Mondego: os dados do Sector C do Outeiro dos Castelos de Beijós (Carregal do Sal)

João Carlos de Senna-Martinez / José Manuel Quintã Ventura / Andreia Carvalho / Cíntia Maurício

823 Novos trabalhos na Lapa da Bugalheira (Almonda, Torres Novas) Filipa Rodrigues / Pedro Souto / Artur Ferreira / Alexandre Varanda / Luís Gomes / Helena Gomes / João Zilhão

837 A pedra polida e afeiçoada do sítio do Neolítico médio da Moita do Ourives (Benavente, Portugal)

César Neves

857 Casal do Outeiro (Encarnação, Mafra): novos contributos para o conhecimento do povoamento do Neolítico final na Península de Lisboa.

Cátia Delicado / Carlos Maneira e Costa / Marta Miranda / Ana Catarina Sousa

873 Stresse infantil, morbilidade e mortalidade no sítio arqueológico do Neolítico Final/ Calcolítico ( $4^{\circ}$ e $3^{\circ}$ milénio a.C.) do Monte do Carrascal 2 (Ferreira do Alentejo, Beja) Liliana Matias de Carvalho / Sofia N. Wasterlain 
885 Come together: O Conjunto Megalítico das Motas (Monção, Viana do Castelo) e as expressões Campaniformes do Alto Minho Ana Catarina Basílio / Rui Ramos

899 Trabalhos arqueológicos no sítio Calcolítico da Pedreira do Poio Carla Magalhães / João Muralha / Mário Reis / António Batarda Fernandes

913 O sítio arqueológico de Castanheiro do Vento. Da arquitectura do sítio à arquitectura de um território João Muralha Cardoso

925 Estudo zooarqueológico das faunas do Calcolítico final de Vila Nova de São Pedro (Azambuja, Portugal): Campanhas de 2017 e 2018 Cleia Detry / Ana Catarina Francisco / Mariana Diniz / Andrea Martins / César Neves / José Morais Arnaud

943 As faunas depositadas no Museu Arqueológico do Carmo provenientes de Vila Nova de São Pedro (Azambuja): as campanhas de 1937 a 1967 Ana Catarina Francisco / Cleia Detry / César Neves / Andrea Martins / Mariana Diniz / José Morais Arnaud

959 Análise funcional de material lítico em sílex do castro de Vila Nova de S. Pedro (Azambuja, Portugal): uma primeira abordagem Rafael Lima

971 O recinto da Folha do Ouro 1 (Serpa) no contexto dos recintos de fossos calcolíticos alentejanos

António Carlos Valera / Tiago do Pereiro / Pedro Valério / António M. Monge Soares

\section{Proto-História}

987 Produção de sal marinho na Idade do Bronze do noroeste Português. Alguns dados para uma reflexão

Ana M. S. Bettencourt / Sara Luz / Nuno Oliveira / Pedro P. Simões / Maria Isabel C. Alves / Emílio Abad-Vidal

1001 A estátua-menir do Pedrão ou de São Bartolomeu do Mar (Esposende, noroeste de Portugal) no contexto arqueológico da fachada costeira de entre os rios Neiva e Cávado Ana M. S. Bettencourt / Manuel Santos-Estévez / Pedro Pimenta Simões / Luís Gonçalves

1015 O Castro do Muro (Vandoma/Baltar, Paredes) - notas para uma biografia de ocupação da Idade do Bronze à Idade Média

Maria Antónia D. Silva / Ana M. S. Bettencourt / António Manuel S. P. Silva / Natália Félix

1031 Do Bronze Final à Idade Média - continuidades e hiatos na ocupação de Povoados em Oliveira de Azeméis João Tiago Tavares / Adriaan de Man

1041 As faunas do final da Idade do Bronze no Sul de Portugal: leituras desde o Outeiro do Circo (Beja)

Nelson J. Almeida / Íris Dias / Cleia Detry / Eduardo Porfírio / Miguel Serra

1055 A Espada do Monte das Oliveiras (Serpa) - uma arma do Bronze Pleno do Sudoeste Rui M. G. Monge Soares / Pedro Valério / Mariana Nabais / António M. Monge Soares

1065 São Julião da Branca (Albergaria-a-Velha) - Investigação e valorização de um povoado do Bronze Final

António Manuel S. P. Silva / Paulo A. P. Lemos / Sara Almeida e Silva / Edite Martins de Sá

1083 Do castro de S. João ao Mosteiro de Santa Clara: notícia de uma intervenção arqueológica, em Vila do Conde Rui Pinheiro 
1095 O castro de Ovil (Espinho), um quarto de século de investigação - resultados e questões em aberto

Jorge Fernando Salvador / António Manuel S. P. Silva

1111 O Castro de Salreu (Estarreja), um povoado proto-histórico no litoral do Entre Douro e Vouga

Sara Almeida e Silva / António Manuel S. P. Silva / Paulo A. P. Lemos / Edite Martins de Sá

1127 Castro de Nossa Senhora das Necessidades (Sernancelhe): uma primeira análise artefactual Telma Susana O. Ribeiro

${ }_{1141}$ A cividade de Bagunte. O estado atual da investigação Pedro Brochado de Almeida

1153 Zoomorfos na cerâmica da Idade do Ferro no NW Peninsular: inventário, cronologias e significado Nuno Oliveira / Cristina Seoane

1163 Vasos gregos em Portugal: diferentes maneiras de contar a história do intercâmbio cultural na Idade do Ferro

Daniela Ferreira

1175 Os exotica da necrópole da Idade do Ferro do Olival do Senhor dos Mártires (Alcácer do Sal) no seu contexto regional

Francisco B. Gomes

\section{Antiguidade Clássica e Tardia}

1191 O uso de madeira como combustível no sítio da Quinta de Crestelos (Baixo Sabor): da Idade do Ferro à Romanização Filipe Vaz / João Tereso / Sérgio Simões Pereira / José Sastre / Javier Larrazabal Galarza / Susana Cosme / José António Pereira / Israel Espi

1207 Cultivos de Época Romana no Baixo Sabor: continuidade em tempos de mudança? João Pedro Tereso / Sérgio Simões Pereira / Filipe Santos / Luís Seabra / Filipe Vaz

1221 A casa romana na Hispânia: aplicação dos modelos itálicos nas províncias ibéricas Fernanda Magalhães / Diego Machado / Manuela Martins

1235 As pinturas murais romanas da Rua General Sousa Machado, n. ${ }^{5}$ 1, Chaves José Carvalho

1243 Trás do Castelo (Vale de Mir, Pegarinhos, Alijó) - Uma exploração agrícola romana do Douro

Tony Silvino / Pedro Pereira

1255 A sequência de ocupação no quadrante sudeste de Bracara Augusta: as transformações de uma unidade doméstica Lara Fernandes / Manuela Martins

1263 Os Mosaicos com decoração geométrica e geométrico-vegetalista dos sítios arqueológicos da área do Conuentus Bracaraugustanus. Novas abordagens quanto à conservação, restauro, decoração e datação Maria de Fátima Abraços / Licínia Wrench

1277 “Casa Romana” do Castro de São Domingos (Cristelos, Lousada): Escavação, Estudo e Musealização Paulo André de P. Lemos

1291 A arqueobotânica no Castro de Guifões (Matosinhos, Noroeste de Portugal): O primeiro estudo carpológico

Luís Seabra / Andreia Arezes / Catarina Magalhães / José Varela / João Pedro Tereso 
1305 Um Horreum Augustano na Foz do Douro (Monte do Castelo de Gaia, Vila Nova de Gaia) Rui Ramos

1311 Ponderais romanos na Lusitânia: padrões, formas, materiais e contextos de utilização Diego Barrios Rodríguez

1323 Um almofariz centro-itálico na foz do Mondego

Marco Penajoia

1335 Estruturas romanas de Carnide - Lisboa Luísa Batalha / Mário Monteiro / Guilherme Cardoso

1347 O contexto funerário do sector da "necrópole NO" da Rua das Portas de S. Antão (Lisboa): o espaço, os artefactos, os indivíduos e a sua interconectividade na interpretação do passado Sílvia Loja, José Carlos Quaresma, Nelson Cabaço, Marina Lourenço, Sílvia Casimiro, Rodrigo Banha da Silva, Francisca Alves-Cardoso

${ }_{1361}$ Povoamento em época Romana na Amadora - resultados de um projeto pluridisciplinar Gisela Encarnação / Vanessa Dias

1371 A Arquitectura Residencial em Mirobriga (Santiago do Cacém): contributo a partir de um estudo de caso Filipe Sousa / Catarina Felício

${ }_{1385}$ O fim do ciclo. Saneamento e gestão de resíduos nos edifícios termais de Mirobriga (Santiago do Cacém)

Catarina Felício / Filipe Sousa

1399 Balsa, Topografia e Urbanismo de uma Cidade Portuária Vítor Silva Dias / João Pedro Bernardes / Celso Candeias / Cristina Tété Garcia

1413 No Largo das Mouras Velhas em Faro (2017): novas evidências da necrópole norte de Ossonoba e da sua ocupação medieval Ricardo Costeira da Silva / Paulo Botelho / Fernando Santos / Liliana Nunes

1429 Instrumentos de pesca recuperados numa fábrica de salga em Ossonoba (Faro) Inês Rasteiro / Ricardo Costeira da Silva / Paulo Botelho

1439 A Necrópole Romana do Eirô, Duas Igrejas (Penafiel): intervenção arqueológica de 2016 Laura Sousa / Teresa Soeiro

1457 Ritual, descarte ou afetividade? A presença de Canis lupus familiaris na Necrópole Noroeste de Olisipo (Lisboa)

Beatriz Calapez Santos / Sofia Simões Pereira / Rodrigo Banha da Silva / Sílvia Casimiro / Cleia Detry / Francisca Alves Cardoso

1467 Dinâmicas económicas em Bracara na Antiguidade Tardia Diego Machado / Manuela Martins / Fernanda Magalhães / Natália Botica

1479 Cerâmicas e Vidros da Antiguidade Tardia do Edifício sob a Igreja do Bom Jesus (Vila Nova de Gaia) Joaquim Filipe Ramos

1493 Novos contributos para a topografia histórica de Mértola no período romano e na Antiguidade Tardia Virgílio Lopes

\section{8. Época Medieval}

1511 Cerâmicas islâmicas no Garb setentrional "português": algumas evidências e incógnitas Constança dos Santos / Helena Catarino / Susana Gómez / Maria José Gonçalves / Isabel Inácio / Gonçalo Lopes / Jacinta Bugalhão / Sandra Cavaco / Jaquelina Covaneiro / Isabel Cristina Fernandes / Ana Sofia Gomes 
1525 Contributo para o conhecimento da cosmética islâmica, em Silves, durante a Idade Média Rosa Varela Gomes

1537 Yábura e o seu território - uma análise histórico-arqueológica de Évora entre os séculos VIII-XII José Rui Santos

1547 A encosta sul do Castelo de Palmela - resultados preliminares da escavação arqueológica Luís Filipe Pereira / Michelle Teixeira Santos

1559 A igreja de São Lourenço (Mouraria, Lisboa): um conjunto de silos e de cerâmica medieval islâmica

Andreia Filipa Moreira Rodrigues

1571 O registo material de movimentações populacionais no Médio Tejo, durante os séculos XII-XIII. Dois casos de "sunken featured buildings", nos concelhos de Cartaxo e Torres Novas Marco Liberato / Helena Santos / Nuno Santos

1585 O nordeste transmontano nos alvores da Idade média. Notas para reflexão Ana Maria da Costa Oliveira

1601 Sepulturas escavadas na rocha do Norte de Portugal e do Vale do Douro: primeiros resultados do Projecto SER-NPVD

Mário Jorge Barroca / César Guedes / Andreia Arezes / Ana Maria Oliveira

1619 "Portucalem Castrum Novum" entre o Mediterrâneo e o Atlântico: o estudo dos materiais cerâmicos alto-medievais do arqueossítio da rua de D. Hugo, nํ. 5 (Porto) João Luís Veloso

1627 A Alta Idade Média na fronteira de Lafões: notas preliminares sobre a Arqueologia no Concelho de Vouzela

Manuel Luís Real / Catarina Tente

1641 Um conjunto cerâmico medieval fora de portas: um breve testemunho aveirense Susana Temudo

${ }_{1651}$ Os Lóios do Porto: uma perspetiva integrada no panorama funerário da Baixa Idade Média à Época Moderna em meios urbanos em Portugal

Ana Lema Seabra

1659 O Caminho Português Interior de Santiago como eixo viário na Idade Média Pedro Azevedo

1665 Morfologia Urbana: Um exercício em torno do Castelo de Ourém André Donas-Botto / Jaqueline Pereira

1677 Intervenção arqueológica na Rua Marquês de Pombal/Largo do Espírito Santo (Bucelas, Loures)

Florbela Estêvão / Nathalie Antunes-Ferreira / Dário Ramos Neves / Inês Lisboa

1691 O Cemitério Medieval do Poço do Borratém e a espacialidade funerária na cidade de Lisboa Inês Belém / Vanessa Filipe / Vasco Noronha Vieira / Sónia Ferro / Rodrigo Banha da Silva

1705 Um Espaço Funerário Conventual do séc. XV em Lisboa: o caso do Convento de São Domingos da Cidade Sérgio Pedroso / Sílvia Casimiro / Rodrigo Banha da Silva / Francisca Alves Cardoso

\section{9. Época Moderna e Contemporânea}

1721 Arqueologia Moderna em Portugal: algumas reflexões críticas em torno da quantificação de conjuntos cerâmicos e suas inferências históricas e antropológicas Rodrigo Banha da Silva / André Bargão / Sara da Cruz Ferreira

1733 Faianças de dois contextos entre os finais do século XVI e XVIII do Palácio dos Condes de Penafiel, Lisboa

Martim Lopes / Tomás Mesquita 
1747 Um perfil de consumo do século XVIII na foz do Tejo: O caso do Mercado da Ribeira, Lisboa Sara da Cruz Ferreira / Rodrigo Banha da Silva / André Bargão

1761 Os Cachimbos dos Séculos XVII e XVIII do Palácio Mesquitela e Convento dos Inglesinhos (Lisboa)

Inês Simão / Marina Pinto / João Pimenta / Sara da Cruz Ferreira / André Bargão / Rodrigo Banha da Silva

1775 "Tomar os fumos da erua que chamão em Portugal erua sancta». Estudo de Cachimbos provenientes da Rua do Terreiro do Trigo, Lisboa

Miguel Martins de Sousa / José Pedro Henriques / Vanessa Galiza Filipe

1787 Cachimbos de Barro Caulínitico da Sé da Cidade Velha (República de Cabo Verde)

Rodrigo Banha da Silva / João Pimenta / Clementino Amaro

1801 Algumas considerações sobre espólio não cerâmico recuperado no Largo de Jesus (Lisboa) Carlos Boavida

1815 Adereços de vidro, dos séculos XVI-XVIII, procedentes do antigo Convento de Santana de Lisboa (anéis, braceletes e contas)

Joana Gonçalves / Rosa Varela Gomes / Mário Varela Gomes

1837 Da ostentação, luxo e poder à simplicidade do uso quotidiano: arqueologia e simbologia de joias e adornos da Idade Moderna Portuguesa Jéssica Iglésias

1849 Os amuletos em Portugal - dos objetos às superstições: o coral vermelho Alexandra Vieira

1865 Cerâmicas de Vila Franca de Xira nos séculos XV e XVI Eva Pires

1879 «Não passa por teu o que me pertence». Marcas de individualização associadas a faianças do Convento de Nossa Senhora de Aracoeli, Alcácer do Sal Catarina Parreira / Íris Fragoso / Miguel Martins de Sousa

1891 Cerâmica de Leiria: alguns focos de produção

Jaqueline Pereira / André Donas-Botto

1901 Os Fornos na Rua da Biquinha, em Óbidos Hugo Silva / Filipe Oliveira

1909 A casa de Pêro Fernandes, contador dos contos de D. Manuel I: o sítio arqueológico da Silha do Alferes, Seixal (século XVI) Mariana Nunes Ferreira

1921 O Alto da Vigia (Sintra) e a vigilância e defesa da costa Alexandre Gonçalves / Sandra Santos

1937 O contexto da torre sineira da Igreja de Santa Maria de Loures Paulo Calaveira / Martim Lopes

1949 A Necrópole do Hospital Militar do Castelo de São Jorge e as práticas funerárias na Lisboa de Época Moderna Susana Henriques / Liliana Matias de Carvalho / Ana Amarante / Sofia N. Wasterlain

1963 SAND - Sarilhos Grandes Entre dois Mundos: o adro da Igreja e a Paleobiologia dos ossos humanos recuperados

Paula Alves Pereira / Roger Lee Jesus / Bruno M. Magalhães

1975 Expansão urbana da vila de Cascais no século XVII e XVIII: a intervenção arqueológica na Rua da Vitória no 15 a 17

Tiago Pereira / Vanessa Filipe

1987 Novos dados para o conhecimento do Urbanismo de Faro em época Moderna Ana Rosa 
1995 Um exemplo de Arqueologia Urbana em Alcoutim: o Antigo Edifício dos CTT Marco Fernandes / Marta Dias / Alexandra Gradim / Virgílio Lopes / Susana Gómez Martínez

2007 Palácio dos Ferrazes (Rua das Flores/Rua da Vitória, Porto): a cocheira de Domingos Oliveira Maia

Francisco Raimundo

2021 As muitas vidas de um edifício urbano: História, Arqueologia e Antropologia no antigo Recreatório Paroquial de Penafiel Helena Bernardo / Jorge Sampaio / Marta Borges

2035 O convento de Nossa Senhora da Esperança de Ponta Delgada: o contributo da arqueologia para o conhecimento de um monumento identitário João Gonçalves Araújo / N’Zinga Oliveira

2047 Arqueologia na ilha do Corvo... em busca da capela de Nossa Senhora do Rosário Tânia Manuel Casimiro / José Luís Neto / Luís Borges / Pedro Parreira

2059 Perdidos à vista da Costa. Trabalhos arqueológicos subaquáticos na Barra do Tejo Jorge Freire / José Bettencourt / Augusto Salgado

2071 Arqueologia marítima em Cabo Verde: enquadramento e primeiros resultados do projecto CONCHA

José Bettencourt / Adilson Dias / Carlos Lima / Christelle Chouzenoux / Cristóvão Fonseca / Dúnia Pereira / Gonçalo Lopes / Inês Coelho / Jaylson Monteiro / José Lima / Maria Eugénia Alves / Patrícia Carvalho / Tiago Silva

2085 Trabalhos arqueológicos na Cidade Velha (Ribeira Grande de Santiago, Cabo Verde): reflexões sobre um projecto de investigação e divulgação patrimonial André Teixeira / Jaylson Monteiro / Mariana Mateus / Nireide Tavares / Cristovão Fonseca / Gonçalo C. Lopes / Joana Bento Torres / Dúnia Pereira / André Bargão / Aurélie Mayer / Bruno Zélie / Carlos Lima / Christelle Chouzenoux / Inês Henriques / Inês Pinto Coelho / José Lima / Patrícia Carvalho / Tiago Silva

2103 A antiga fortificação de Quelba / Khor Kalba (E.A.U.). Resultados de quatro campanhas de escavações, problemáticas e perspectivas futuras Rui Carita / Rosa Varela Gomes / Mário Varela Gomes / Kamyar Kamyad

2123 Colónias para homens novos: arqueologia da colonização agrária fascista no noroeste ibérico Xurxo Ayán Vila / José Mạ . Señorán Martín 


\title{
POVOAMENTO PRÉ-HISTÓRICO NAS ÁREAS MONTANHOSAS DO NO DE PORTUGAL: O ABRIGO1 DE VALE DE CERDEIRA
}

\author{
Pedro Xavier ${ }^{1}$, José Meireles ${ }^{1,2}$, Carlos Alves ${ }^{3}$
}

\begin{abstract}
RESUMO
Na década de 90 do século passado, prospeções realizadas nas áreas serranas do NO de Portugal conduziram à identificação do sítio arqueológico conhecido como Abrigo 1 de Vale de Cerdeira, situado na Serra da Cabreira (NO Portugal, máx. alt. $1262 \mathrm{~m}$ ). O conjunto de evidências recuperado nas escavações arqueológicas permitem situar a ocupação da jazida entre os finais do VI/inícios do V milénio a.C. No âmbito de um projeto de doutoramento iniciado em 2017 encontra-se, atualmente, a ser estudada a coleção lítica do citado abrigo, numa dupla vertente. A primeira relativa ao estudo tecno-tipológico, identificando os objetivos da produção artefactual e, a segunda, relacionada com a classificação e caracterização das diferentes matérias-primas exploradas e manipuladas pelas comunidades pré-históricas.
\end{abstract}

Palavras-Chave: NO Portugal, Serra da Cabreira, Mesolítico Final, Matérias-primas, Indústria lítica.

\begin{abstract}
In the 1990's set of field surveys took place in the mountains of NW Portugal, leading to the discovery of the archaeological site named 'Rock Shelter 1 of Cerdeira Valley', situated in Cabreira Mountain (NW Portugal, max. alt. 1,262 m). The evidences recovered from the archaeological excavations established the shelter occupation between the end of the VI / beginning of the $5^{\text {th }}$ millennium BC. Since 2017, within the context of an ongoing Phd project, the stone tool assemblage of the shelter is being analysed, in a double perspective. The first one relates to the complete techno-typological, identifying the objectives of the stone tool production and the second concerns with the classification and characterisation of different raw-materials exploited by the prehistoric communities.
\end{abstract}

Keywords: NW Portugal, Cabreira Mountain, Late Mesolithic, Raw materials, Lithic industry.

\section{INTRODUÇÃO}

Na década de 90 do século passado desenvolveu-se, por intermédio de um dos autores do presente trabalho (J. Meireles), um programa de investigação dedicado ao reconhecimento, nas áreas serranas de média altitude do NO de Portugal, de um modelo de ocupação associado à presença dos derradeiros grupos de caçadores-recolectores pré-históricos. Este projeto teve como referência os estudos rea- lizados, na segunda metade do séc. XX, nas serras setentrionais da Galiza, a partir dos quais se identificou um conjunto de jazidas enquadráveis nos períodos Epipaleolítico e Mesolítico (Ramil Rego, 1997). Os resultados das prospeções intensivasrealizadas nos conjuntos montanhosos do NO de Portugal, permitiram eleger a Serra da Cabreira (alt. max. 1262 $\mathrm{m})$, como área preferencial de intervenção do mencionado projeto. Entre os locais referenciados e sondados, destacou-se o denominado Abrigo 1 de Vale

\footnotetext{
1. LandS/Lab2PT - Laboratório de Paisagens, Património e Território, Universidade do Minho, Braga, Portugal; pedroxavy@gmail.com

2. ICS - Instituto de Ciências Sociais, Universidade do Minho, Braga, Portugal; jmeireles@uaum.uminho.pt

3. Laboratório de Paisagens, Património e Território (FCT UID/AUR/04509/2013; FEDER COMPETE POCI-O1-0145-FEDERo07528) e Dept. Ciências da Terra/Escola de Ciências, Universidade do Minho, Braga, Portugal. Contacto: casaix@dcOt.uminho.pt
} 
de Cerdeira, cujos trabalhos de escavação e estudo do conjunto artefactual foram já objeto de um conjunto de publicações (Meireles, 2009, 2010, 2013). Mais recentemente, desde 2017, o conjunto lítico deste sítio arqueológico encontra-se a ser analisado no âmbito de um programa doutoral (P. Xavier), considerando duas abordagens de investigação. A primeira, relativa à análise tecno-tipológica e à compreensão dos sistemas técnicos de produção e respetivas cadeias operatórias e, uma segunda, que procura identificar e caracterizar as diferentes matérias-primas e recursos litológicos explorados e manipulados pelas comunidades pré-históricas da Serra da Cabreira, procurando ainda colocar e debater hipóteses de trabalho quanto à localização de pontos de aprovisionamento e recolha.

O presente texto tem como propósito a realização de um primeiro balanço das atividades desenvolvidas até ao momento. Assim, e após a apresentação das opções metodológicas e procedimentos técnicos adotados na observação das matérias-primas, serão discutidos os primeiros resultados deste estudo, juntamente com os da análise tecnológica.

\section{O ABRIGO I DE VALE DE CERDEIRA}

Neste apartado pretendemos dar a conhecer a localização do abrigo, o seu enquadramento físico e uma pequena nota referente à sequência estratigráfica e às estruturas arqueológicas identificadas. Esta caracterização será extremamente sucinta, uma vez que a descrição destes parâmetros encontra-se bastante detalhada na bibliografia já publicada sobre o sítio arqueológico (Meireles, 2009, 2010 e 2013). A este respeito, realce-se o trabalho de 2010 , onde poderá ser consultada uma descrição bastante pormenorizada, tanto da sequência sedimentar como das duas estruturas de combustão registadas na base da UE 1 . O Abrigo 1 de Vale de Cerdeira ( $41^{\circ} 37^{\prime} 30.0^{\prime \prime} \mathrm{N}, 8^{\circ}$ 05'31.3”W) situa-se na União de Freguesias de Vilar Chão e Anjos, concelho de Vieira do Minho, distrito de Braga (Figura 1).

Posicionado a $660 \mathrm{~m}$ de altitude absoluta, desfruta de uma localização privilegiada, comprovada pelo acesso a recursos hídricos (junto a uma linha de água), amplo domínio territorial (controlo de vias naturais de acesso à zona ocidental da Serra da Cabreira) e ainda pela proximidade de filões de quartzo e consequentes recursos de matérias-primas (Meireles, 2009, 2013). Esta área, vertente norte do mon- te da Feteira em plena Serra da Cabreira, enquadra-se no padrão típico de algumas regiões graníticas, compostas por granitos calcoalcalinos porfiróides de grão grosseiro, os quais, com frequência, por via de processos de evolução subárea e subcutânea, juntamente com fenómenos de meteorização química e de erosão diferencial, definem um modelado conhecido como caos de blocos que conformam espaços protegidos, seja sob a forma de abrigos, seja através de áreas ao ar-livre cercadas por conjuntos de afloramentos rochosos (Meireles, 2009, 2013). O Abrigo 1 de Vale de Cerdeira (Imagem 2) resultou da fracturação longitudinal de um grande bloco de granito porfiróide que originou duas áreas abrigadas, designando-se a superior de Abrigo 1, constituindo uma área de $36 \mathrm{~m}^{2}$, dos quais $20 \mathrm{~m} 2$ foram alvo de intervenção arqueológica (idem) (Figura 2). A sequência estratigráfica registada, inferior a $1 \mathrm{~m}$ de espessura, contempla 3 níveis, denominados, da base para o topo, como UE1, UE2 e U3 e um conjunto artefactual superior a 30 mil peças $O$ estudo que tem vindo a ser realizado incide na UE-1 e UE-2, não contemplando a UE-3, dado o carácter altamente perturbado e incaracterístico deste depósito, condicionando qualquer consideração de ordem cronológica e cultural.

Na base da UE-1 identificaram-se duas estruturas de combustão, cujas amostras de carvão vegetal permitiram a obtenção de duas datações radiométricas C14, situando a ocupação humana do abrigo entre os finais do VI (GrN-25614, $6240 \pm 50$ BP: $5316-$ 5056 cal. BC $2 \sigma$ ), inícios do $\mathrm{V}$ milénio a.C. (GrN$-25613,6090 \pm 4$ o BP: $5207-4853$ cal. BC 2 o) (idem).

\section{OBSERVAÇÃO DAS MATÉRIAS-PRIMAS}

A análise das matérias-primas tem assentado, por ora, essencialmente sobre as de origem local, consistindo em diferentes variedades de quartzo. Tal decisão radica no carácter verdadeiramente hegemónico dos recursos locais que representam, tanto na UE-1 como na UE-2, mais de $98 \%$ dos efetivos totais. É nossa intenção porém, com o desenrolar dos trabalhos, efetuar um pequeno ensaio de caracterização e de hipóteses de proveniência das matérias-primas exógenas, representadas por diferentes variedades de sílex, o qual marcará presença na dissertação final de doutoramento. 


\subsection{Classificação dos Quartzos}

Como afirmado, o quartzo é a matéria-prima dominante na coleção lítica recuperada no Abrigo 1 de Vale de Cerdeira. A consulta da cartografia geológica coincidente com a localização do abrigo (Carta Geológica 6-C, Cabeceiras de Basto) e das áreas limítrofes, permite-nos compreender que este mineral é um vasto e abundante recurso à escala regional, disponível tanto através de filões associados a falhas, como em corpos geológicos aplítico-pegmatíticos.

Nos estudos anteriores de J. Meireles (2009, 2010, 2013), no que respeita aos quartzos, foi efetuada uma divisão em duas grandes categorias: quartzo hialino ou cristal de rocha e outras variedades de quartzo, de acordo com a distinção estabelecida por V. Mourre (1996), entre quartzo automorfo e xenomorfo, referentes ao hábito do cristal e às diferentes condições ambientais de formação que potenciam o surgimento de diferentes variedades.

$\mathrm{Na}$ análise que tem vindo a ser empreendida foi mantida esta primeira separação, adaptando-se ainda, para a categoria do quartzo xenomorfo, uma tipologia de base cromática e de transparência, compreendo as seguintes variedades: leitoso, translúcido, róseo, cinzento e fumado. Sendo conscientes das insuficiências apontadas por alguns autores quanto ao emprego destas classificações (e. g. Driscoll, 2010), foi mantida a sua aplicação, dada a utilização de designações idênticas em estudos mineralógicos e pela circunstância de proporcionar uma primeira ordenação de carácter expedito, de fácil aplicação e que poderá ainda relacionar-se com diferentes ambientes geológicos.

Decidiu-se ainda seguir a proposta de classificação de Martínez Cortizas e C. Llana (1996), que averigua da presença e/ou ausência de duas variáveis morfo-estruturais do quartzo: textura granulada e planos de cristalização, fissuras ou fraturas. Nesse sentido, os autores definem 4 grupos, a saber: NN (sem grão/ sem planos); NS (sem grão/com planos internos); SN (granulado/sem planos) e SS (granulado/com planos internos) (idem). Relacionando processos de formação do quartzo às suas propriedades mecânicas, esta classificação poderá auxiliar a descortinar critérios de aquisição e seleção de matéria-prima e identificar alguns constrangimentos de ordem técnica associados a cada grupo (Lombera-Hermida, 2008), sendo comum a sua aplicação por parte de um conjunto de autores se dedicam ao estudo de indústrias líticas em quartzo (e.g. Rodríguez-Rellán,
2010; Peña Alonso 2015). Com efeito, e na situação particular do conjunto de Vale de Cerdeira e ainda que esta análise não se encontre encerrada, é relevante assinalar a grande relação do quartzo hialino com a categoria ' $\mathrm{NN}$ ' e que, invariavelmente, este corresponda ao grupo mais apto para o talhe, destinado, frequentemente, à obtenção de produtos alongados e utensílios microlíticos.

Noutro sentido, os trabalhos de campo permitiram compreender que o quartzo existente na área imediatamente envolvente ao abrigo, que ocorre em filões, é de tipo cataclástico, apresentando-se finamente granulado e com cavidades, resultante da fracturação da falha aqui presente, enquadrando-se nas categorias SN e SS da referida classificação. Não obstante, a imensa maioria da matéria-prima registada nas duas unidades estratigráficas em estudo é de tipo 'NS', presente, por sua vez, noutros locais situados a maior distância da jazida arqueológica. Tal facto é revelador de um comportamento seletivo no momento da recolha de matéria-prima por parte comunidades pré-históricas da Serra da Cabreira.

\subsection{Análises Laboratoriais}

No intuito de levar a cabo uma caracterização dos distintos quartzos da coleção, tem sido aplicadas algumas técnicas laboratoriais afetas ao domínio de conhecimento das Ciências da Terra. Desde uma fase precoce do estudo, por forma a promover a inviolabilidade dos artefactos, foi conferida total primazia a técnicas de cariz não-destrutivo. Tal decisão assentou no valor patrimonial e cultural que reconhecemos ao espólio arqueológico, mas também na perspetiva de que, no futuro, outros procedimentos e projetos de investigação possam ser desenvolvidos sobre os mesmos materiais, eventualmente com recurso a técnicas de maior acuidade.

Entendemos aqui o conceito de não-destrutivo num duplo significado: primeiro, na circunstância óbvia de evitar qualquer alteração ou dano na peça sujeita a procedimento analítico e, segundo, no sentido de ser reprodutível, permitindo a repetição de testes ou a realização de diferentes análises no mesmo artefacto (Xavier e Alves, 2019). Com efeito, verificam-se técnicas que, sendo destrutivas, exigindo o corte ou fragmentação do artefacto, possibilitam, ao invés, a realização de vários conjuntos de testes, evitando continuados danos no material arqueológico.

O conjunto das técnicas laboratoriais ensaiadas consistiram: observação de peças do Microscópio 
Electrónico de Varrimento (MEV) para obtenção de caracterizações químicas e informações relativas à análise textural e estrutural; análises RAMAN, importantes para o conhecimento da composição química dos minerais; estudos por florescência de raios-X (XRF), igualmente importantes na descrição química, tanto global como pontual e, finalmente, Análises de Imagiologia Hiperespectral as quais, através da avaliação quantitativa de coordenadas cromáticas permitem, de forma reproduzível e objetiva, determinar a cor de uma determinada peça. Algumas das dificuldades recorrentemente experimentadas nestes ensaios, prenderam-se com a superfície irregular dos artefactos, restringindo a aplicabilidade de alguns procedimentos e ainda com a escassa capacidade de penetração de algumas das técnicas e equipamentos, aspeto particularmente importante na análise e deteção das inclusões fluídas e minerais, descritas no próximo ponto.

\subsection{Estudo das inclusões}

A considerável homogeneidade química e cristalográfica entre diferentes variedades de quartzo dificulta, sobremaneira, a deteção das fontes de aprovisionamento (Cousseran 2002). Uma possível aproximação aos locais de proveniência destes materiais radica na identificação de inclusões, sejam estas sólidas (outros minerais), gasosas ou líquidas, que ocorrem no seio de um mineral aquando da sua formação, providenciando informações sobre o ambiente de formação e, consequentemente, da sua origem (idem). No âmbito do nosso estudo, a observação, ao microscópio petrográfico, de artefactos elaborados em quartzo hialino e translúcido com vista ao reconhecimento de inclusões, têm-se se revelado frutífera.

Com efeito, parte substancial do esforço investido nas técnicas laboratoriais mencionadas no ponto anterior destinou-se à determinação do material constituinte das inclusões. No que concerne às de tipo mineral, os estudos realizados indiciam que possam corresponder a schorlite e elbaíte; no que respeita às fluídas, os resultados tem sido pouco claros, em função, em parte, da já referida pouca capacidade de penetração no interior das peças por parte dos equipamentos laboratoriais e da circunstância de as análises terem sido efetuadas nos artefactos por inteiro, mantendo a sua integridade e descartando qualquer corte, polimento ou fratura. Não obstante, a identificação das inclusões minerais permitiu, de certo modo, atribuir diretrizes ao trabalho de campo que discriminamos no ponto seguinte.

\subsection{Trabalhos de Campo}

Qualquer estudo de proveniência implica a realização de prospeções para o reconhecimento de corpos geológicos e recolha de amostras que possam ser contrastadas com o material arqueológico. Assumem, assim, particular importância a cartografia geológica disponível, bem como outros recursos, nomeadamente o portal SIORMINP (http://geoportal.lneg.pt/geoportal/egeo/bds/siorminp/) - Sistema de Informação de Ocorrência e Recursos Minerais Portugueses - que congrega indicações de antigas explorações mineiras.

As variedades de quartzo presentes na coleção de Vale de Cerdeira são suscetíveis de se encontrarem em filões de quartzo e formações pegmatíticas. A consulta da cartografia geológica e realização dos primeiros trabalhos de campo permitiu-nos compreender da impossibilidade logística e temporal de conhecer e caracterizar todos os corpos geológicos situados na envolvente do abrigo. Em simultâneo, a recolha da variedade de quartzo dominante na coleção-leitoso, 'NS'-, poderia ter ocorrido numa multitude de pontos distintos. Assim, de forma a tornar este estudo mais frutífero, sobretudo no que respeita à localização de eventuais pontos de aprovisionamento, tornou-se necessário reorientar a pesquisa para a busca de tipos mais raros, nomeadamente quartzo róseo, fumado, hialino e, mais recentemente, quartzo com inclusões.

O programa de prospeções empreendido até à data, insistindo, particularmente, na deteção de corpos pegmatíticos posicionados numa área até $15 \mathrm{~km}$ de distância para com a jazida, possibilitou o registo de mais de 200 ocorrências.

Apesar de constrangimentos pontuais, como problemas de acessibilidade ou destruição e fragmentação de determinados corpos geológicos, alguns dos pontos detetados são merecedores de destaque, sobretudo o local conhecido como Muro Alto, situado a cerca de $5 \mathrm{~km}$ da jazida arqueológica. Trata-se de um corpo pegmatito, providenciando diferentes tipos de quartzo, entre os quais quartzo róseo, fumado, translúcido e com inclusões. Atualmente, o local encontra-se bastante modificado daquela que seria a sua configuração natural, fruto da intensa exploração mineira de que foi alvo no decorrer das décadas de 40 e 50 (inf. pes. C. Leal Gomes). De acordo com 
a mesma fonte e com base na análise geológica da informação disponível, antes da exploração, o sítio poderia apresentar um imponente esporão de quartzo, com mais de 6 metros de altura, constituindo um verdadeiro marco paisagístico no meio envolvente.

Neste momento, o sítio foi já intervencionado no contexto do nosso trabalho, tendo-se recolhidos algumas amostras, semelhantes a algumas a algumas peças presentes na coleção arqueológica. A presença de uma densa vegetação e falta de limpeza do terreno tem impossibilitado, momentaneamente, a continuação dos trabalhos em segurança.

\section{PRIMEIROS RESULTADOS}

Seguidamente apresentaremos os primeiros resultados do estudo das matérias-primas e da análise tecnológica separados por unidade estratigráfica. Tratando-se de informações preliminares e de carác-ter provisório não será de estranhar, face ao que posteriormente se encontrará na dissertação doutoral, alterações de carácter pontual relativas a algumas percentagens e valores que serão agora mencionados.

\subsection{Unidade Estratigráfica 1}

A imensa maioria ( $75 \%$ ) das mais de 13600 peças recuperadas da UE-1 correspondem a material residual (restos de talhe + esquírolas), seguido, a uma larga distância, pelos produtos de lascamento (lascas + produtos alongados) que correspondem a $20 \%$ e os núcleos com uns meros $2 \%$. O índice de transformação assume uma importância meramente vestigial inferior a $2 \%$.

Os dados das matérias-primas, no contexto geral da coleção, encontram-se sintetizados na Imagem 3. Verifica-se uma preponderância do quartzo automorfo, de cor leitosa, seguido do translúcido. O quartzo hialino representa $12 \%$ enquanto, por sua vez, os recursos exógenos ficam-se por $1 \%$. No que concerne aos grupos morfoestruturais, a variedade NS, associada, fundamentalmente, a quartzos leitosos e translúcidos é a mais importante, enquanto a $\mathrm{NN}$, de forma geral associada com o cristal de rocha, fica-se pelos $22 \%$. O quartzo com textura granulada é, em termos globais, pouco expressivo (Figura 3 ). No domínio dos produtos de lascamento, observa-se uma grande incidência de suportes fraturados, na ordem dos $55 \%$, tanto nas lascas como nos produtos alongados. Tal circunstância encontra-se relacionada pelas características mecânicas da matéria-prima, sendo reconhecível, em ensaios experimentais, a produção de enormes quantidades de restos de talhe (Driscoll, 2011). Entre as fraturas mais comuns encontram-se, em ambos os tipos de produtos, as de tipo Buril de Siret e as transversais. Porém, se no caso das lascas, as proporções são idênticas, nos produtos alongados as transversais representam quase metade do total das fraturas e as de tipo Buril de Siret não mais do que $17 \%$. Os talões lisos são a grande maioria e correspondem, em ambas as categorias, a mais de metade. Observa-se, no caso dos produtos alongados uma maior preferência pelo emprego de cristal de rocha (33\%), face às demais matérias-primas. O quartzo de tipo NN representa $29 \%$ e $16 \%$ nos produtos alongados e nas lascas, respetivamente. Nestas, o tipo de quartzo dominante é leitoso, de tipo NS, na ordem dos $40 \%$.

No que concerne aos núcleos, as estratégias predominante são a multipolar (29\%), bipolar sobre bigorna $(24 \%)$ e prismática (14\%). Entre os volumes trabalhados sobre bigorna, identifica-se uma preferência pelos de menor dimensão e, no que concerne ao método prismático, pratica-se, usualmente, sobre os prismas de quartzo. Apesar da já referida abundância de matéria-prima no contexto geológico onde se encontra a jazida, cerca de $52 \%$ dos núcleos foram intensamente explorados e $20 \%$ encontram-se mesmo esgotados. De assinalar, a recolha de 43 prismas de quartzo, sem estigmas de exploração, parte dos quais pode ser entendida como reserva de matéria-prima. Quanto aos utensílios, o baixo índice de transformação corresponde, em termos quantitativos, a 279 unidades, contando-se 92 sobre lasca, 179 utensílios microlíticos e 8 diversos. Entre os micrólitos registam-se 9 produtos alongados retocados, 8 truncaturas, 2 microfuradores, 63 pontas. 4 indeterminados e 92 geométricos - 55 segmentos e 37 trapézios (Figura 4).

Entre os denominados 'utensílios de fundo comum', as 3 classes mais representadas, por ordem decrescente, são furadores, entalhes e lascas retocadas. Considerando as matérias-primas, não se observa uma gestão diferenciada, comparativamente aos suportes não retocados. Comportamento diferente, porém, verifica-se nos microlíticos, dado que $10 \%$ destes foram elaborados a partir de recursos exógenos; é igualmente nesta subcategoria onde é mais significativo o emprego do quartzo hialino, representando mais de $70 \%$ e da variedade $\mathrm{NN}$, superior a $80 \%$. 
O tipo de retoque predominante - com independência relativamente à matéria-prima, mas também à subcategoria, isto é, de substrato ou microlítica apresenta-se direto, contínuo, muito abrupto, marginal, escamoso, sendo ainda, por vezes, apoiado ou sobre bigorna. Quanto às pontas microlíticas, que serão, posteriormente, objeto de um estudo detalhado, imperam as de secção e morfologia triangular, embora também se conheçam de corpo fusiforme e ainda, um outro conjunto, evidenciando uma solução mais original, onde se pratica um aproveitamento das características naturais do suporte, na circunstância um produto extraído do ápice ou cabeça do cristal de quartzo, que através de retoque mínimo e, com frequência, limitado à zona distal, é transformado numa ponta.

No domínio do sistema técnico de produção, validam-se e reforçam-se as conclusões assinaladas nos trabalhos anteriores (Meireles, 2009, 2010 e 2013). Regista-se, assim, uma estratégia direcionada para a obtenção de duas categorias de produtos. A primeira, com maior significado quantitativo, representada, no essencial, por lascas de módulo reduzido e, ocasionalmente, por produtos alongados obtidos através da exploração de núcleos multipolares e bipolares; a segunda, assente no método prismático, direcionada para o fabrico de pequenas lamelas, tendo em vista a sua posterior transformação utensílios e que resulta de uma cadeira operatória particular, decorrente da exploração de prismas de quartzo hialino e leitoso, tirando o máximo partido das características morfo-estruturais do romboedro cristalino.

\subsection{Unidade Estratigráfica 2}

São significativas as semelhanças, em variados aspetos, entre ambas as unidades estratigráficas, a começar pelo valor percentual das distintas categorias. Assim, na UE-2, o material residual a volta a cifrar-se nos $75 \%$ e os produtos de lascamento nos $20 \%$. Contudo, ressalve-se uma redução do índice de transformação, desta feita 1,6\%, suportado pela redução no número de utensílios, contabilizando 154 unidades. No capítulo das matérias-primas, contrastando com a UE-1, há um significativo reforço dos recursos exógenos e do quartzo de tonalidade leitosa, que consubstancia já mais de metade da totalidade das litologias. Em sentido inverso, o cristal de rocha conhece uma diminuição global, porém com uma aplicação mais direcionada, no âmbito da obtenção de produtos alongados e da configuração de utensi- lagem lamelar. Os quartzos com textura granulada são uma pequena parte dos recursos manipulados, o que poderá estar relacionado, mais do que com a sua menor ou maior disponibilidade, com a reduzida aptidão para o talhe que, de uma forma genérica, parecem apresentar (Figura 5).

Os produtos de lascamento fraturados voltam a representar mais de 50\%, em ambas as subcategorias. É na categoria dos produtos alongados onde se regista o maior emprego do sílex surgindo, após o quartzo hialino, como o segundo recurso utilizado. Tal circunstância não se observa nas lascas onde é o quartzo leitoso e translúcido de variante NS, o que mais se destaca. Os talões lisos e bolbos desenvolvidos são os mais comuns, tanto em lascas como em produtos alongados, ainda que nestes se observe uma significativa representação de bolbos esbatidos e de talões lineares.

Apesar das grandes similitudes dos dois conjuntos, há pontuais dissemelhanças, como o número muito mais reduzido de núcleos que, por ora, contabilizam apenas 108 unidades. Destas, $38 \%$ correspondem a fragmentos dos quais não possível compreender a estratégia de exploração praticada. Regista-se um incremento dos núcleos bipolares sobre bigorna com $27 \%$, seguido dos multipolares, $23 \%$ e dos prismáticos (fundamentalmente de uma plataforma), com $20 \%$. Com a exceção dos núcleos prismáticos, os quais se encontram, grosso modo, entre o esgotado e o intensamente explorado, os demais apresentam, maioritariamente, um reduzido número de extrações. De destacar a concentração de volumes de matéria-prima do grupo NN no conjunto dos núcleos prismáticos, tanto em quartzo hialino como leitoso, associado aos maiores requisitos técnicos exigidos por este método de exploração. Registe-se ainda a presença de 56 prismas de quartzo por explorar, entendidos como reserva de matéria-prima. Ainda que, no domínio percentual, o número de utensílios não se diferencie muito entre as duas unidades, a UE-2 concentra, em termos quantitativos, um número bem mais baixo, mais concretamente 154 unidades, das 103 sobre lamela, 47 sobre lascas e 4 diversos (Figura 6).

Começando pela utensilagem lamelar, os mais representativos são os segmentos, seguidos das pontas microlíticas e dos produtos alongados retocados. Há uma notória diminuição das armaduras trapezoidais (somente duas unidades), destacando-se ainda a presença de uma forma triangular. Dentro 
das pontas microlíticas (redução muito substancial face à UE-1, de 6o para 23) continua a manifestar-se a tendência para peças de morfologia e secção triangular, não faltando, tal como mencionado para a UE-1, peças elaboradas a partir do ápice do cristal de quartzo e ainda de 3 outros exemplares, que se destacam do conjunto pelas suas maiores dimensões e pesos e cujo significado terá de ser, evidentemente, valorado. O sílex é particularmente aplicado na configuração de segmentos e de produtos alongados retocados, não sendo empregue, porém, eà imagem do observado na UE-1, na elaboração de pontas. Com efeito, nas pontas, o quartzo utilizado limita-se aos grupos NN e NS, nas variantes hialina e translúcida. Em ambas as unidades estratigráficas, a realização das armaduras microlíticas assentou na transformação, por retoque, de produtos de módulo reduzido. De modo complementar, recorreu-se à técnica da rutura transversal, conhecida pelo seu carácter expedito, consistindo na obtenção de uma superfície de fratura perpendicular ao eixo do suporte do qual se seleciona um fragmento para a realização da peça (Prieto, 2000-2001). Em sentido inverso, não há evidência do emprego da técnica do microburil.

Na utensilagem sobre lasca, mantêm-se a maior importância de lascas retocadas, furadores e entalhes, por ordem de representatividade. Neste subconjunto, não parece ter-se verificado uma particular gestão dos recursos litológicos, mantendo-se os mesmos padrões observados nos suportes não retocados.

O sistema técnico de produção da UE-2 é idêntico ao descrito para a UE-1, tanto ao nível das categorias de produções, como das cadeias operatórias. Assim, o aspeto mais distintivo do segundo nível estratigráfico prende-se com a presença de um reduzido conjunto de materiais de pedra polida, constituído por um pequeno machado em silimanite/fibrolite, 1 fragmento (talão) de um outro machado e ainda 4 diversos e, também pela recuperação de 20 fragmentos de cerâmica, a maioria sem decoração. Entre os decorados contam-se 2 com decoração incisa simples, 1 de tipo "boquique" e 1 de impressão simples, com paralelos nas cerâmicas atribuíveis ao Neolítico Antigo da estação duriense do Prazo (Monteiro-Rodrigues, 2008; Meireles, 2010, 2013),

\section{CONSIDERAÇÕES FINAIS}

Uma das motivações subjacentes à realização do estudo de caracterização das matérias-primas que contemplasse, igualmente, a discussão de potenciais pontos de aprovisionamento, deveu-se à manifesta insuficiência deste tipo de análises em regiões e contextos geológicos - do qual o NO Peninsular constitui um bom exemplo - onde o quartzo é dominante e, em sentido contrário, o sílex é raro ou mesmo inexistente (Lombera Hermida e Rodríguez-Rellán, 2010).

No que mais diretamente concerne à deteção de eventuais fontes de aprovisionamento os resultados são, até ao momento, algo limitados, em função da própria composição química monótona do quartzo, da variabilidade que, por vezes, se deteta no mesmo filão e formação geológica (podendo conter distintas variedades) e dos já assinalados constrangimentos ao nível dos trabalhos de campo e procedimentos laboratoriais. Não obstante, o estudo das inclusões permanece em aberto e a identificação de corpos pegmatíticos donde se recuperou quartzo com inclusões, entre os quais o citado Muro Alto, poderá ainda providenciar o estabelecimento de correspondências entre material arqueológico e amostras geológicas. De todo o modo, os trabalhos de campo permitiram, num raio de $15 \mathrm{~km}$ em redor da jazida, a identificação de mais de 200 pontos. A informação daqui proveniente encontra-se a ser sistematizada num software de sistema de informação geográfica (QGIS), com o propósito de ser disponibilizada numa plataforma de acesso livre. No mesmo sentido, a recolha de amostras geológicas serviu de pretexto à constituição de uma futura litoteca que servirá como coleção de referência no desenvolvimento de futuros programas de investigação.

$\mathrm{O}$ regime de aprovisionamento de recursos líticos praticado pelas comunidades pré-históricas da Serra da Cabreira seria, essencialmente, baseado nas matérias-primas locais, à semelhança do conhecido noutras regiões nacionais e ibéricas para o período do Mesolítico Final (e.g Carvalho, 2009;. Martí Oliver et al., 2009), devendo ocorrer no domínio da realização de outras atividades - embedded procurement, na expressão de L. Binford (1979) - não se descartando, contudo, uma recolha mais direta ou direcionada de determinados recursos, como o quartzo hialino. Relativamente aos recursos exógenos, que não foram abordados neste trabalho, será relevante o conhecimento da sua proveniência, dada a informação que poderá providenciar relativamente a processos de intercâmbio e de interação social entre grupos humanos. 
Relativamente à indústria lítica, dever-se-á assinalar, em primeira instância, a total adequação daquilo que são os objetivos da produção lítica aos recursos disponíveis. Tal poderá ser observado, entre outros exemplos, na cadeia operatória que tira partido das características morfo-estruturais dos prismas de quartzo e no conjunto de armaduras que são elaboradas a partir de uma extração procedente do ápice do cristal. Estes recursos permitiram a constituição de um conjunto de clara vocação cinegética, atendendo à proporção, no seio da utensilagem, de armaduras, tanto geométricas, como pontas microlíticas (Meireles, 2013).

Relativamente à UE-1, a obtenção das duas datações radiométricas mencionadas no início deste texto, juntamente com a análise do conjunto lítico, permite a sua adscrição a uma fase terminal do Mesolítico Final ou Recente. A descoberta do Abrigo de Vale de Cerdeira, ao propiciar, juntamente com a identificação de outras jazidas, entre quais o Prazo (Monteiro Rodrigues, 2008) ou a Barca do Xerez de Baixo (Araújo e Almeida, 2013), um panorama mais diverso e enriquecido, do que até então tinha sido admitido nos modelos dominantes para a compreensão do Mesolítico em território nacional (Carvalho, 2009), vem ainda contribuir para desmistificar a suposta atipicidade associada às indústrias em quartzo, já assinalada igualmente por outros autores, a propósito dos materiais pré-históricos da Galiza (Ramil Rego, Blanco Sanmartín e Rodríguez Pérez, 2016). As datas, aparentemente tardias, têm paralelo em território nacional, no estuário do Tejo ou na Costa Alentejana, onde o modo de vida caçador-recolector perdurou até cerca de $4750 \mathrm{aC}$ (Zilhão, 200o). No mesmo sentido, atendendo somente à cronologia e ao predomínio dos segmentos no quadro dos utensílios geométricos, Vale de Cerdeira tem correspondência, por exemplo, com o concheiro de Vidigal (Odemira) (Carvalho, 2009) ou com o concheiro das Amoreiras (Alcácer do Sal) (Nukushina, 2015). Finalmente, em relação à UE-2, para a qual não se possuem datações, esta reproduz, essencialmente, os mesmos processos técnicos e de gestão da matéria-prima observados na UE-1. O traço mais distintivo consiste assim no surgimento de inovações tecnológicas representadas pelo pequeno conjunto cerâmico e de artefactos em pedra polida, itens integrantes no denominado "pacote neolítico" e associáveis a comunidades produtoras. A valorização destes elementos, juntamente com a cronologia relativa permite-nos, por ora sem mais desenvolvimentos, enquadrar esta ocupação no Neolítico Antigo. Todavia, no domínio das estratégias gerais de subsistência, podermos estar perante comunidades predadoras, para as quais as "novidades" adotadas teriam, sobretudo numa primeira fase, implicações de carácter social e que, somente a longo prazo, se refletiriam na esfera económica (Monteiro-Rodrigues, 2008).

\section{AGRADECIMENTOS}

FCT - Fundação Ciência e Tecnologia - Bolsa de Doutoramento ref. SFRH/BD/120806/2016 de Pedro Xavier.

Lab2PT - Laboratório de Paisagens, Património e Território (AUR/04509) financiado pela FCT através de fundos nacionais e quando aplicável do cofinanciamento do FEDER, no âmbito dos novos acordos de parceria PT2020 e COMPETE 2020 POCI-O1-0145-FEDER-007528.

Prof. Leal Gomes, docente da Universidade do Minho e investigador afeto ao Lab2PT, pelas informações prestadas sobre fontes de matéria-prima e pela participação em algumas atividades de campo.

\section{BIBLIOGRAFIA}

ARAÚJO, Ana C.; ALMEIDA, Francisco (2013) - Barca do Xerez de Baixo. Um testemunho invulgar das últimas comunidades de caçadores-recolectores do Alentejo interior. Memória d'Odiana, 2aㅡ Série. 332 p.

BINFORD, Lewis (1979) - Organization and formation processes: looking at curated technologies. Journal of Anthropological Research 35, pp. 255-273

CARVALHO, António Faustino (2009) - O Mesolítico Final em Portugal. In Monografías Arqueológicas Vol. 44, pp. 33-68. In P. Utrilla \& Montes Lourdes (Eds.), El Mesolítico Geométrico en la Península Ibérica Monografias Arqueológicas 44 (. Universidad de Zaragoza, pp. 33-68

COUSSERAN, Sylvie (2002) - [Résumé de thèse] Les inclusions fluides, un outil pour la discrimination des quartz archéologiques: application au problème de circulation du quartz dans les Alpes occidentales et lombardes. Réalisation d'un premier référentiel de données sur les quartz. Bulletin de La Société Préhistorique Française, 99(4), pp. 833-838.

DRISCOLL, Killian, (2010) - Understanding quartz technology in early prehistoric Ireland. School of Archaeology, University College Dublin, Dublin. Unpublished PhD thesis. http:// www.lithicsireland.ie/PHD_Quartz_lithic_ technology_CONTENTS.html. 
DRISCOLL, Killian (2011) - Vein quartz in lithic traditions: an analysis based on experimental archaeology. Journal of Archaeological Science, 38(3), 734-745. https://doi. org/10.1016/j.jas.2010.10.027

FUERTES PRIETO, Natividad (2000-2001) - El modo de produción de los microlitos geométricos: el caso de la cueva de "El Espertín”, Lancia, 4, Revista de Prehistoria, Arqueología e Historia Antigua del Noroeste Peninsular, Universidad de León, pp. 51-70.

LOMBERA-HERMIDA, Arturo de (2008) - Quartz morphostructural groups and their mechanical implications. Museologia Scientifica e Naturalistica, 3 (January 2008), pp. 1-5. https://doi.org/10.1516o/1824-2707/488

LOMBERA-HERMIDA, Arturo de; RODRÍGUEZ RELLÁN, Carlos (2010) - Gestión y Estrategias de abastecimiento de las materias primas locales (cuarzo, cuarcita y pizarra) en la Prehistória del NW Peninsular. In S. Domínguez-Bella, J. Ramos Muñoz, J. M. Gutiérrez López, \& M. Pérez rodríguez (Eds.), Minerales y Rocas en las sociedades de la Prehistóris (Grupo de I, pp. 49-6o).

MARTÍNEZ CORTIZAS, Antonio; LLANA RODRÍGUEZ, César (1996) - Morphostructural variables and the analysis of their effect on quartz blank characteristics. In: Non - Flint Stone Tools and the Palaeolithic Occupation of the Iberian Peninsula. MOLONEY, Norah; RAPOSO, Luís; SANTONJA, Manuel (Eds). Tempus Reparatum, Oxford. 649, pp. 49-53.

MARTÍ OLIVER, Bernat; AURA TORTOSA, J. Emili; JUAN CABANILLES, Joaquín, GARCÍA-PUCHOL, Oreto; FERNÁNDEZ LOPEZ DE PABLO, Javier (2009) - El Mesolítico Geométrico de tipo "Cocina” en el País Valenciano. In PILLAR UTRILLA, Maria \& MONTES RAMÍREZ, Lourdes (Eds.), El Mesolítico Geométrico en la Península Ibérica Monografias Arqueológicas 44, Universidad de Zaragoza, pp. 205-258.

MEIRELES, José (2009) - Os primeiros povoadores. A Pré-história Antiga do Minho. In PEREIRA, Paulo (coord.) A Identidade do Minho. Braga: Conselho Cultural da Universidade do Minho, pp. 20-66.

MEIRELES. José (2010) - Os últimos caçadores-recolectores da Serra da Cabreira (NO de Portugal). O Abrigo 1 de Vale de Cerdeira (Vieira do Minho). In BETTENCOURT, Ana. M.S., ALVES, Maria Isabel C., MONTEIRO-RODRIGUES, Sérgio (eds.). Variações Paleoambientais e Evolução Antrópica no Quaternário do Ocidente Peninsular, pp. 83-96.

MEIRELES, José (2013) - O Abrigo I de Vale de Cerdeira, In. BETTENCOURT, Ana M.S, A Pré-História do Noroeste Português, CRUZ, Ana \& OOSTERBEEK, Luíz (eds)., Arkeos 36, Braga/Tomar, pp. 116-123.

MONTEIRO-RODRIGUES, Sérgio (2011) - Pensar o Neolítico Antigo. In Estudos Pré-Históricos: Vol. XVI, p. 393.

MOURRE, Vincent (1996) - Les industries en quartz au Paléolithique. Terminologie, méthodologie et technologie. $\mathrm{Pa}$ léo, 8(1), 205-223. https://doi.org/10.3406/pal.1996.116o.
NUKUSHINA, Diana (2014) - Geometric microliths as chronological and cultural markers in the Sado shell middens? Reflections from Amoreiras (Alcácer do Sal, Portugal). Nailos, 2, pp. 89-122.

PEÑA ALONSO, Paloma de la (2015) - A qualitative guide to recognize bipolar knapping for flint and quartz. Lithic Technology, 40(4), 316-331. https://doi.org/10.1080/0197 7261.2015.1123947

RAMIL REGO, Eduardo (1997) - La transición del Paleolítico Superior al Neolítico en las sierras septentrionales de Galicia. Una aproximación preliminar: II Congresso de Arqueología Peninsular. Tomo I. Zamora: Fundación Rei Afonso Henriques, pp. 273-285.

RAMIL REGO, Eduardo, BLANCO SANMARTÍN, Paz; RODRÍGUEZ PÉREZ, Mar (2016) - Los últimos cazadores-recolectores en el occidente cantábrico. Portvgalia, Nova Série, XXXVII, pp. 151-161.

RODRÍGUEZ RELLÁN, Carlos (2010) - Unha perspectiva tecnolóxica e experimental das industrias sobre lousa, cristal de rocha e cuarzo na Prehistoria Recente do Noroeste Peninsular. 1251 .

XAVIER, Pedro, ALVES, Carlos (2019) - Non-destructive studies of prehistoric lithic material culture in the search for sources of geologic raw materials: An overview of techniques and issues. Cadernos Do Laboratorio Xeoloxico de Laxe, 41, 123-140. https://doi.org/10.17979/cadlaxe.2019.41.1.5820

ZILHÃO, João (200o) - From the Mesolithic to the Neolithic in the Iberian peninsula In DOUGLAS PRICE, Theron (Ed.), Europe's First Farmers, Cambridge: Cambridge University Press, pp. 144-182. 


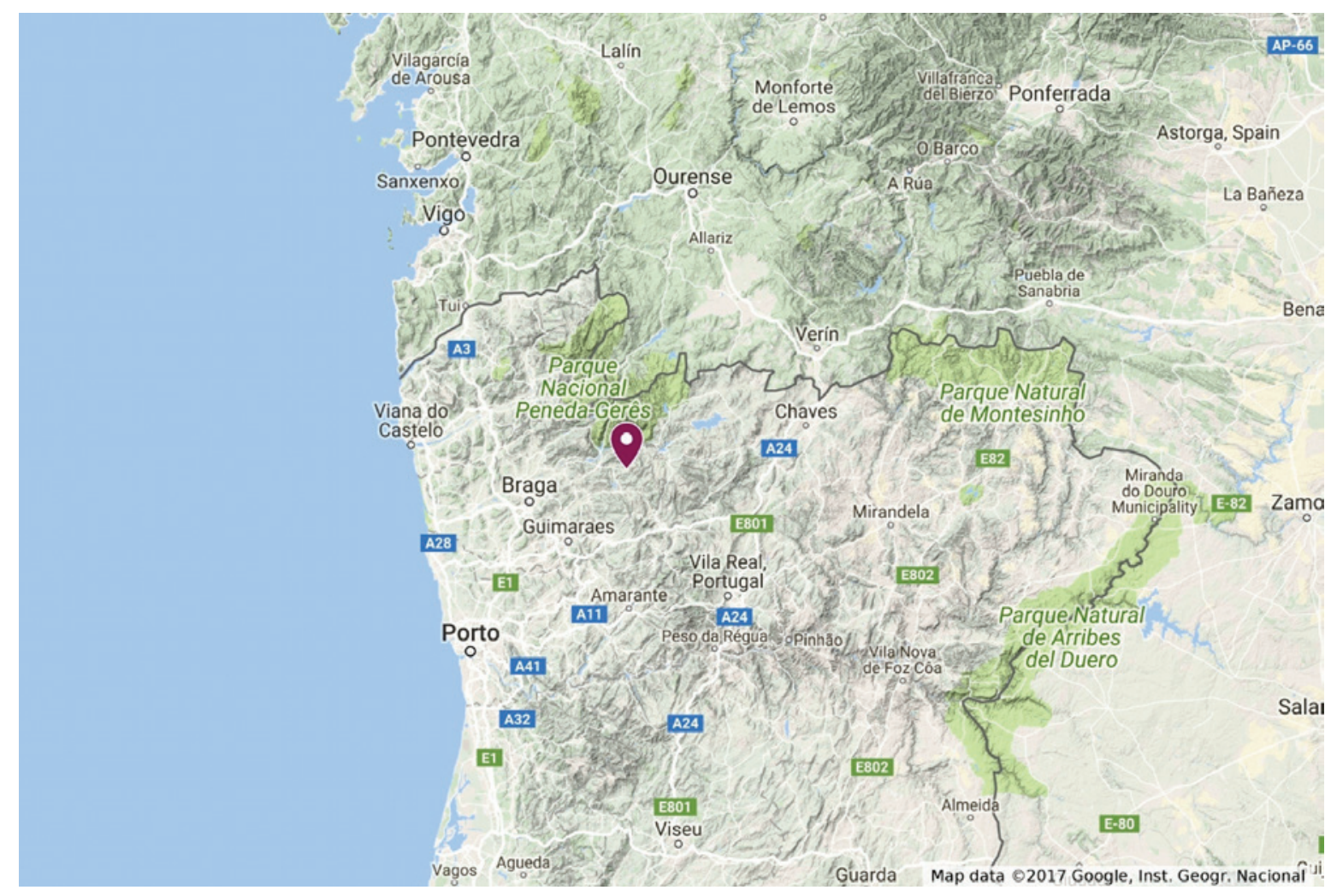

Figura 1 - Localização Abrigo I de Vale de Cerdeira.



Figura 2 - Perspetiva Frontal Abrigo 1 de Vale de Cerdeira. 


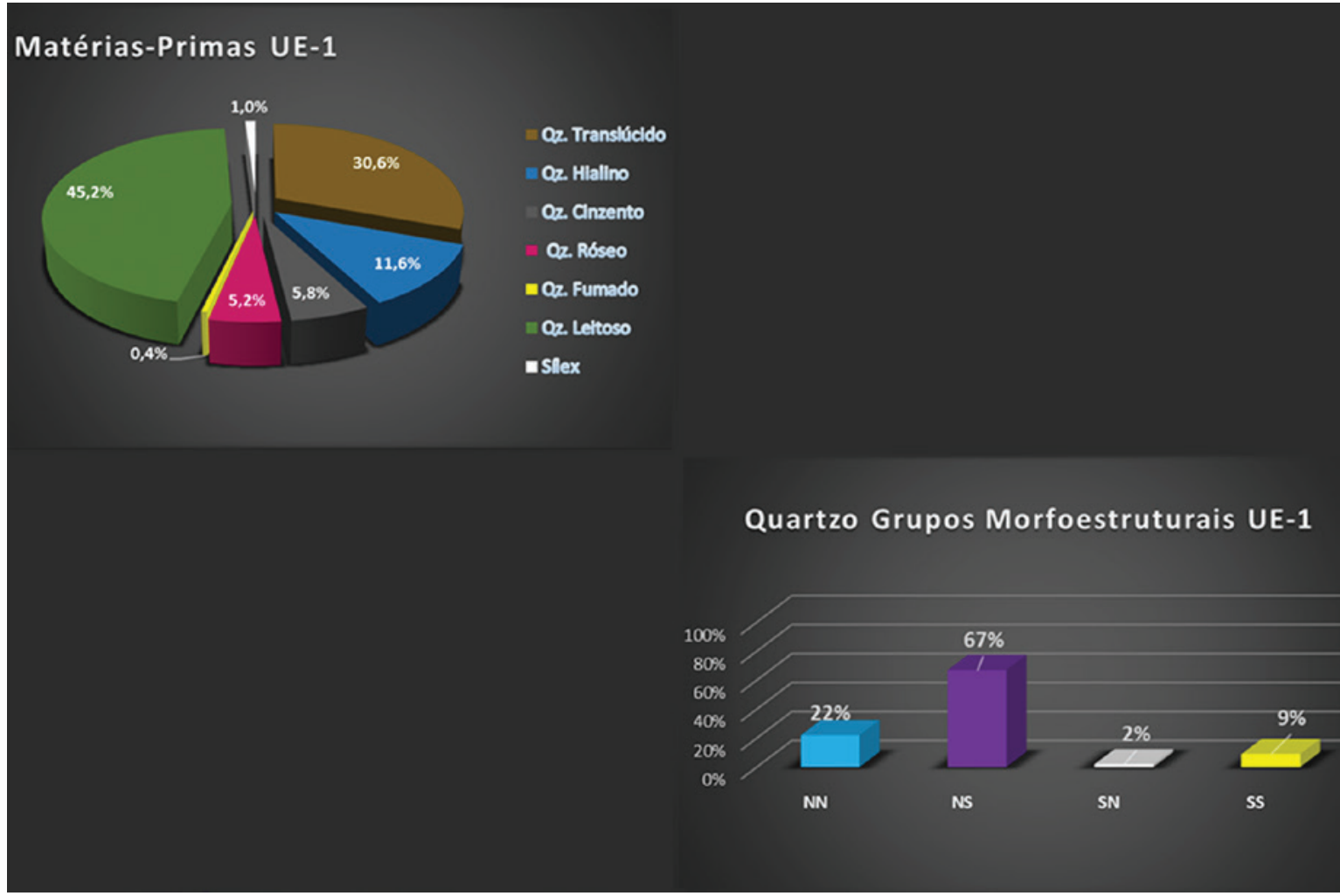

Figura 3 - Matérias-Primas UE-1.
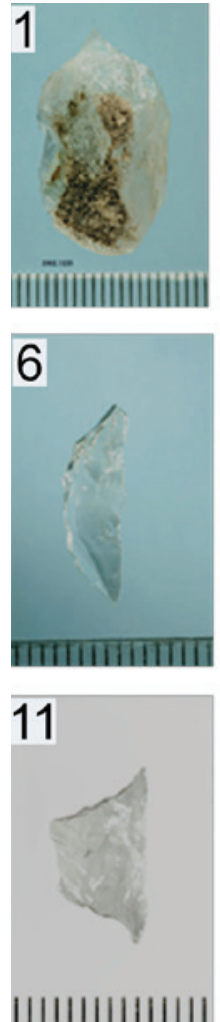
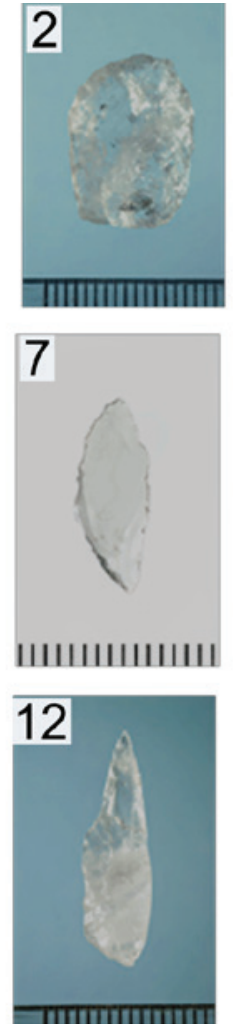
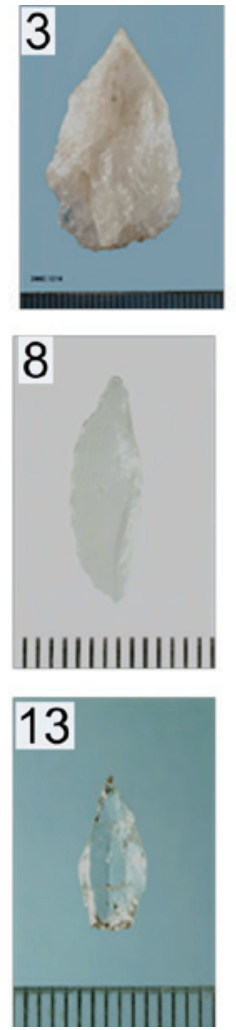
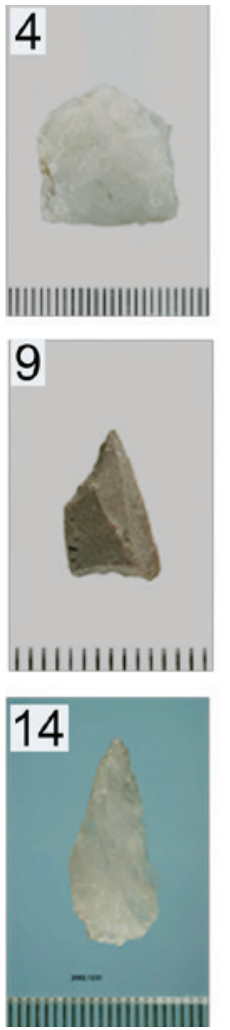

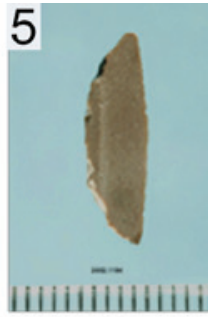

10
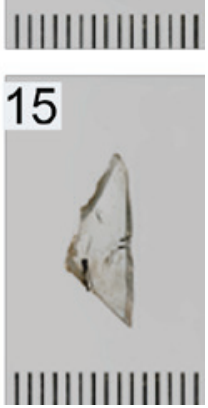

Figura 4 - Utensílios UE-1 (1. Micro-furador; 2 e 4: Raspadeiras; 3. Buril; 5 a 8: Segmentos; 9 a 11: Trapézios; 12 a 15: Pontas Microlíticas. Créditos: Manuel Santos, Museu Regional de Arqueologia D. Diogo de Sousa). 


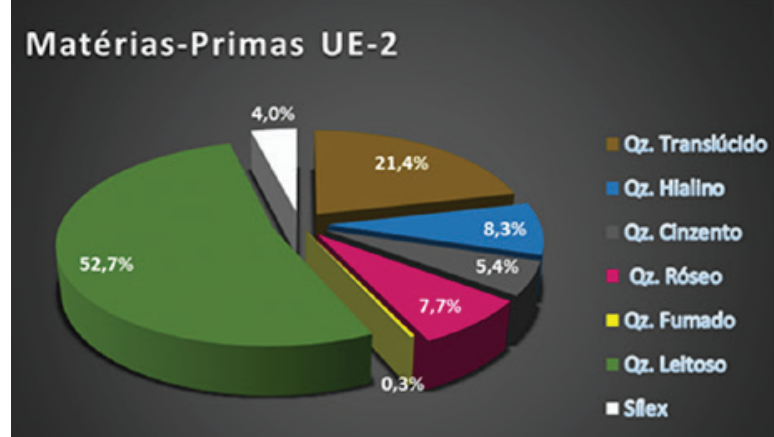

Quartzo Grupos Morfoestruturais UE-2

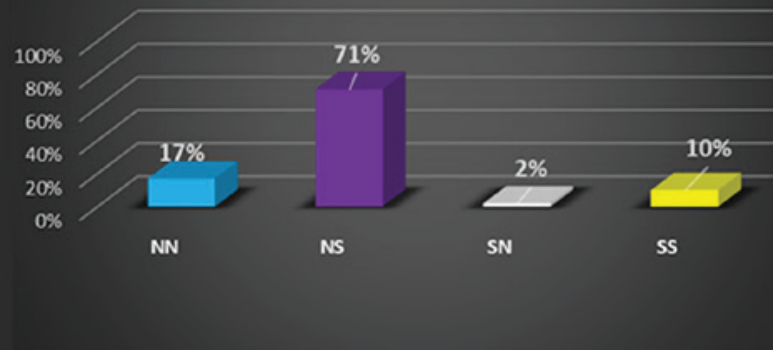

Figura 5-Matérias-Primas UE-2.
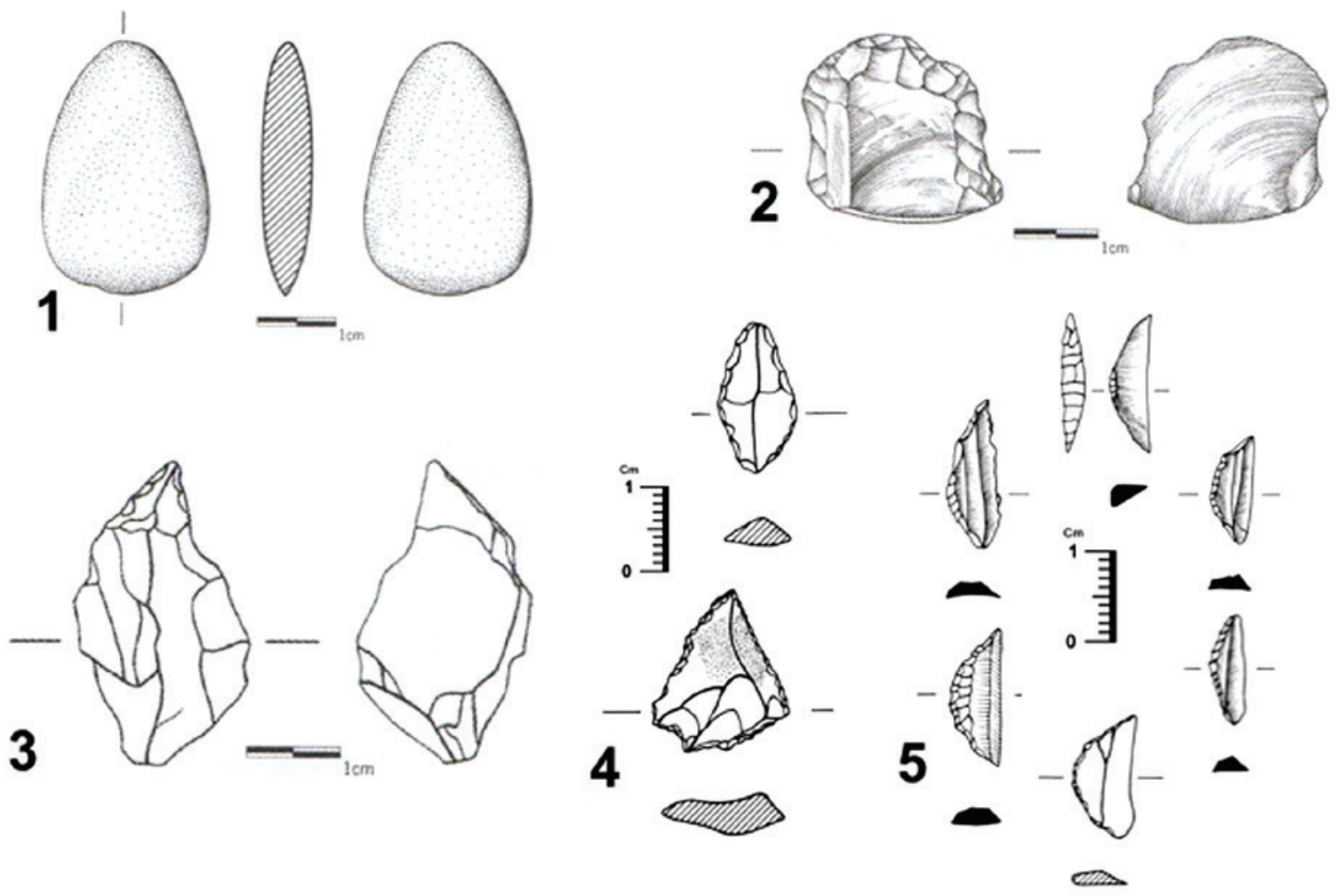

Figura 6 - Utensílios UE-2 (1. Machado de pedra polida; 2. Raspadeira; 3. Furador; 4. Pontas Microlíticas; 5. Segmentos. Créditos: Amélia Marques, Museu Regional de Arqueologia D. Diogo de Sousa). 



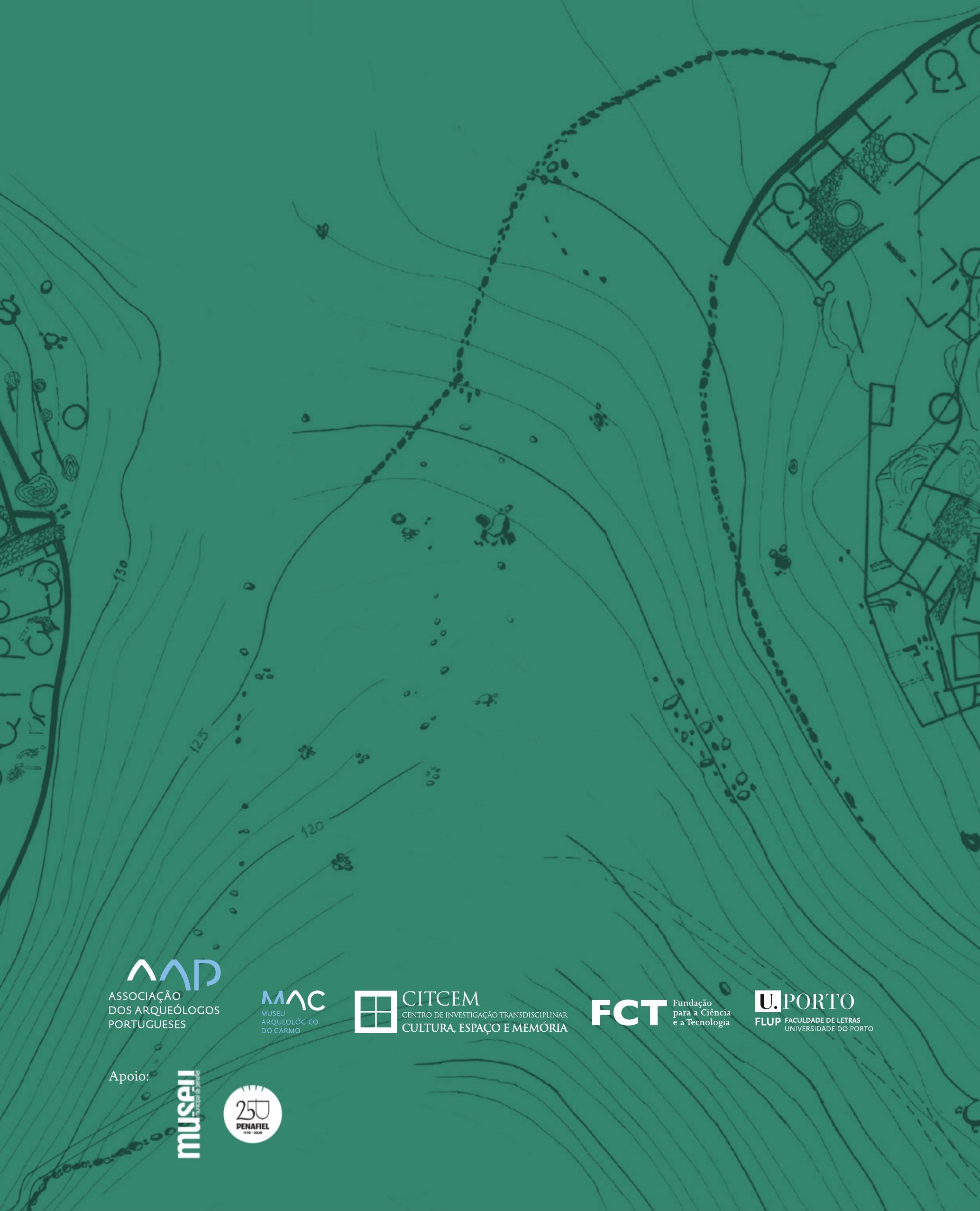

